\title{
Niger Delta Conflict, Social Egoism and the Ethics of Civility
}

\author{
Laleye Solomon A. ${ }^{1}$ \\ ${ }^{1}$ Department of Philosophy, Adekunle Ajasin University \\ Correspondence: Laleye Solomon A., Department of Philosophy, Adekunle Ajasin University, Akungba Akoko. Ondo \\ State. Nigeria.
}

\author{
Received: January 22, 2018 Accepted: February 5, 2018 Online Published: May 9, 2018 \\ doi:10.5539/res.v10n2p159 \\ URL: https://doi.org/10.5539/res.v10n2p159
}

\begin{abstract}
The paper re-examines the problem of violent conflict in the Niger/Delta region which threatens the mono-economy and corporate existence of Nigeria. It seeks to navigate beyond the common causes of the problem to include a frequently excluded cause, which is, the social-egoism of the groups that constitute the major stakeholders in the conflict. The paper, therefore, argues that the pursuit of group's interests devoid of concomitant consideration for others, (including future generations) and the environment would continue to impact negatively on resolution efforts and consequently, impede on peaceful co-existence. Therefore, it proposed the display of the ethics of civility on the part of the stakeholders in handling the conflict constructively. The paper employed the quantitative method of research in Philosophy, it specifically adopted the analytic and prescriptive approaches of the method. The analytic approach clarifies concepts such as ethics of civility, stakeholders, social egoism, etc. so as to remove ambiguity. The prescriptive approach proposed the inculcation of the ethics of civility in inter-personal relations, including human dealings with the ecosystem.
\end{abstract}

Keywords: Civility Ethics, Multinational Oil Corporations, Social egoism, Stakeholders, Violent conflict

\section{Introduction}

Literature abounds on the prevalence of violent conflicts in contemporary world, including the oil resource- based Niger Delta region of Nigeria. Like many of the major social challenges confronting the nation, spontaneous efforts were made to nip the problem on the bud. In this regard, institutions were established to address the developmental needs of the oil bearing communities, poverty alleviating programmes were designed, amnesty programme were emplaced for the militant youths who voluntarily surrendered arms, militarization of the region to impose peace and occasional review of revenue derivation principle. These have yielded marginal success in ensuring lasting peace in the region largely because the approaches toward implementation of the resolution techniques are undermined particularly by, the pursuits of group interests devoid of sense of civility by each of the major parties in the conflict.

The three major groups in the conflict, namely the Indigenous people of the oil rich Niger Delta region, the Multinational Oil Corporations (MNOC), operating in the region and the Federal Government of Nigeria (FGN) pursues interests that are inimical to effective resolution of the conflict; the interests pursued are essentially group-based interests rather than general interest. Suffice it to say, intra and inter group relations foster better and, peaceful co-existence enhanced when personal interests of members of a group or interests of smaller groups within a larger group are sufficiently reconciled with those of other groups in the socio-political sphere. The pursuant of self or group interests devoid of the consideration for others is a negation of the existentialists' notion of being with others or being in the world.

Two major relations necessary for the enhancement of human race are discernable in society, these include: relation among humans and between humans and the environment. Both relations date back to time immemorial. In the case of the former, recourse could be made to the Hobbesian hypothetical state of nature where interpersonal relations were essentially egocentric largely because of the immoderate appetite and aversion of the human persons. The individual man in this state strived to appropriate all that are beneficial in the society to himself alone, even at the detriment of the survival of other individuals thereby threatening the continuous existence of human society. In spite of this, the reality is that, "man's biological configuration, psychological state and the peculiarity of his faculty" made him a social being that does not only require the company of others but also better actualises his potentials within human society. (Muyiwa Falaiye \& Anthony Okeregbe 2016: 151). Unfortunately, incessant violence in contemporary human society made it controversial if truly, human society has transcended the state of nature because it continually drifts more on the pendulum towards the state than being better position to harness the benefits of civil society. In contemporary Nigeria for instance, security of lives and properties constitute serious challenge to individuals, groups and institutions. Cases of rape, assassination, theft, abduction are on the increase. The law and its enforcement institutions are centuries behind the geometric progression of 
contemporary crime against humanity by humans themselves. In other words, like the hypothetical state of nature, where "life is solitary, nasty, brutish, poor and short," (Thomas Hobbes 1962:80),victims of crime in contemporary Nigerian society are deprived of properties and often times, lives by "the fittest" and "strongest" thereby compounding the complexity of the society. In other words, the complexity of the society is a reflection of the nature of the human elements and the socio-political arrangements under which they lived. These impose varieties of need and desperate desires to satisfy them at the face of scarce resources on the people. Aptly put, "the complexity of human being generates in him, therefore, a multiplicity of purposes or goals which he pursues" either as individuals or as groups (Dipo Irele 1998: 39). In the pursuit of these goals, more often, recognition is not given to the feelings, interests and aspirations of others a typical of the situation in the Niger Delta: where inter personal and group relations lacked adequate recognition for the feelings and aspirations of others.

In the case of the later, especially if the creationist account is anything to go by, the environment preceded the emergence of humans. At the early stage of human existence, humans and the environment relate with one another with reasonable modicum of compassion and care. Aggressive and reckless exploitation of nature by human beings to meet basic and existential needs were not too pronounced. In return, occurrences of natural calamities such as volcanic eruptions, storms, ocean slides and boisterous wind were minimal particularly in Africa. However, colonialism and industrial revolution heralded an environmentally unfriendly industrial development with its attendant creation of capitalist world economic order. This was aided and abetted by the advancement in science and technology that increased man's capacity to dominate and control nature even beyond initial comprehension of man: Man's basic and existential needs were relatively met through their control, domination and exploitation of the environment. These, as experience has lamentably shown are devoid of adequate consideration for the coming generations of humans and non- humans in the environment. Exploitation of the environment is particularly directed at satisfying immediate needs of present generation. Thomas Meginns (1982: 705) aptly captured this scenario when he writes that, "contemporary man has lost sense of respect through his philosophy of exploitation". This brings to the fore the care- free attitudinal display towards the environment as well as the grave implications of such treatment on both the present and future generations of human beings. Suffice it to say, the treatment of the Niger Delta environment is critical to the analysis of the conflict that constantly ravage the region and threaten the social and political fabrics of Nigerian society.

\section{The Niger Delta Region and the Question of Resource Control}

Nigerian society is a pluralistic society with numerous ethnic nationalities, traditions and belief systems. The mainstay of the country' economy is oil. Oil derived from the Niger Delta region, contributes immensely to the nation's revenue. "Statistics hold that 95\% of the total revenue for the Nigerian government is generated from oil and gas" (Paul Haaga 2015: 199). The Niger Delta region which is the focus of this paper is situated on the continental margin of the gulf of Guinea on the west coast (equatorial) of central Africa. It lies between Latitude $3^{0}$ and $6^{\circ} \mathrm{N}$ and Longitude $5^{0}$ and $8^{0} \mathrm{E}$ (Olugbenga Ige 2017: 22), specifically, in the south-south and south-west of Nigeria, It covers a land area of about 75,000 square kilometres (UNDP 2000:15), comprising of nine states of Akwa Ibom, Bayelsa, Abia, Cross Rivers, Rivers, Edo, Delta, Imo and Ondo. Oil discovered outside these aforementioned states in Nigeria are yet to be explored. The area under reference in this paper is mainly populated by the Ijaws, Urhobo, Ogonis, Edos, Isoko, Yorubas and other sub-groups. Apart from the human resource and oil, the region is naturally endowed with large deposits of resources that includes; bitumen, forestry and wildlife. Given the terrain of the area, the traditional occupation of the people is farming and fishing. But these sources of livelihood are threatened by environmental pollution caused by oil exploration and exploitation: there is reduction of arable land, destruction of wild life and fish reserves. The assaults on the communities' natural environment, abuse of the rights and deprivation of the means of livelihood of the people in the region strained the relationship between the oil bearing communities and the staffers of the Multinational Oil Corporations. These have consequently resulted into incessant conflicts manifesting in the forms of abduction, arson, oil production disruption, pipeline vandalization and ransom requests by the aggrieved and disenchanted youths from the region. In essence, three groups namely; the Multinational Oil Corporations represented by Shell BP, Mobil, Exxon, Chevron, Total etc., the oil bearing communities in the region visibly represented by the militant youths and the Federal Government of Nigeria, the supposedly arbiter between the first and second groups are discernable in the Niger Delta crisis. Each of the groups pursues interests and values that seem irreconcilable. It is the egoistic pursuits of these diverse interests by members of each of the parties that the author refers to as social egoism. I shall return to this shortly.

\section{The Visible Activities of the Major Stakeholders in the Niger Delta Conflict}

The stakeholders are referred to in this paper as those that have legitimate interest or concern in what goes on in the Niger Delta region. Broadly speaking, all Nigerians could be said to be stakeholders in the Niger Delta project by virtue of the direct or indirect concern or impacts which the activities in the region have on their existence. However, the major stakeholders in the Niger Delta conflict can be categorized to include "the voluntary, involuntary and unknown stakeholders." (ICAN 2014: 286-287). The unknown stakeholders include the ecosystem represented by the aquatic lives, 
animals and plants of different kinds who are at the receiving ends of the degradation and pollution orchestrated by the activities of the oil and gas industries. The involuntary stakeholders are the indigenous people of the oil bearing communities of the region. This category of people become a major stakeholder not necessary by choice but by exigencies of nature and technological development. Perhaps, if they had another chance they would prefer to be on the other side of the divide. Finally, the Multinational Oil Corporations and the Federal Government of Nigeria are voluntary stakeholders.

The activities of the Multinational Oil Corporations operating in the Niger Delta region of Nigeria remains the core issue in the violent conflicts prevalent in the region. The activities of the corporations are alleged to have, among other things, violated the traditional environmental ethics of the people, which encourages one "not to take more than one needs from nature..." (Segun Ogungbemi 2010: 169) . The relation between Multinational Oil Corporations and the Niger Delta environment is detrimental to the existence of the ecosystem and human inhabitants of the area. The resort to violence is seen by the indigenous people of the oil producing areas as a means of checkmating the reckless exploitation and pollution of the environment, which they believed impacted negatively on the survival of the present as well as the future generations of humans and non-humans in their environment. The people seem to be too passionate about the environment because land, which is one of the components of the environment, traditionally among Africans is held in trust by the living for the present and future generations, the rationale being that, it bonds human and ancestral communities as well as sacred forces of the universe. (Magessa 1997: 244). Plants of medicinal value, rivers of traditional significance and some species of animals have either gone into extinction or polluted by spillage thereby depriving younger generation the practical description or benefits of such plants, animals and rivers.

Scholars such as J. Meginns (1982: 705) and Paul W. Taylor (1986) have emphasized the need to respect the natural world by dealing with nature with caution. According to them, we should nourish nature the way we nourish ourselves because when we harm nature we either directly or indirectly harm ourselves. To Taylor, the natural world constitutes a community of biological life, where there exist an interdependence relation of humans with the environment that is capable of establishing liveable lives for both human and non-humans. He further observed that all organisms are teleological centre pursuing their own good and that, human beings while possessing inherent worth are partners in a natural world where other beings and entities also possess inherent worth so that humans cannot claim to be inherently superior to other living things (99-100). As much as the author of this paper shares the sentiments of these scholars on the need to treat nature with utmost care and respect, the author is equally more concern about the future generations of human and non-humans in the Niger Delta environment. The environment should not be depleted for present complacency devoid of consideration for the future.

It is true that opinions differ among ethicists on whether or not the non human elements in the environment deserve any obligation concerning how it should be treated by the humans. For instance, Thomas Aquinas, Aristotle and Immanuel Kant argued that, rationality does not only differentiate the humans from non-humans, it is the basis for determining the scope of those to whom the humans have moral responsibilities towards. In the same vein, Bentham, J.S. Mill, Louis Pojman and Peter Singer argued in favour of sentience as a veritable factor in assessing what humans ought not to inflict harm on.

Beyond rationality and sentience parameters of western philosophers, traditional Africans cum indigenous people of the Niger Delta believed that animals, plants and mountains needed to be treated with care; some of them possess healing power and constitute metaphysical links between the living-dead (ancestors), deities, spirit and the people, hence, they are revered rather than destroyed.

Without prejudice to the debate, what is good and capable of enhancing the well being of the present and future humans and non human elements of the environments can be rationally derived. When the environment suffers degradation, as the case in the Niger Delta, it endangers the survival as well as the continuity of generations of humans and non-humans. It threatens the naturalness of the air they inhale, the water they drink, the food they eat above all; it makes them dependent rather than being self sufficient in the supply of basic existential needs like food since farmlands, crops, water sources and economic trees are destroyed. It is instructive for the Multinational Oil Corporations to be more sensitive to the degradation of the environment, devise means of replacing devastated components of the environment and to be more committed to compensating for whatever is loss to environmental degradation. It is true that, the traditional goal of any business is profit maximization but business organization that pride ethics in its operations tend to run smoothly and profitably than others that relegates the roles of ethics in business. Distributive justice requires that those that are responsible or that benefit from injury should bear the burden of rectifying whatever has been damaged.This is the upshot of Olanrewaju's argument when he writes that, "oil companies should take account of the social, ethical, and environmental perspectives of their operations (Olanrewaju, 2014) .In the case of the Niger Delta region, it is the communities rather than the Multinational Oil Corporations that shoulder the burden of pollution.

Given the alleged violation of the traditional ethics of the indigenous people in the oil producing communities of the Niger 
Delta, the obvious cases of unemployment, deprivation of means of livelihood, abject poverty and neglect of the region by the Federal government, the contretemps culminated into frustrations and grievances hence, the aggrieved Youths formed militant groups, which are united in the promotion and protection of the oil bearing communities' interests. Such groups include; Movement for the Emancipation of Niger Deltans (MEND), Movement for the Survival of Ogoni People (MOSOP), the Niger Delta Avengers (NDA). This does not suggest that the formation of some of the militant groups were devoid of ulterior motives. The initial non-violent agitations of some of these groups metamorphosed into violent agitations for the control of the oil resource. Suffice it to say, the Ogoni Bill of Right of 1990 and the Kaiama Declaration by the Ijaw Youth in 1998 were premised on the belief that through the control of the oil source by the indigenous people of the Niger Delta the social, political and economic dislocations of the region would automatically transmute into fortunes for the people and the region. This vision for resource control gained momentum and expanded to include agitation for political right of self determination. Consequently, allegiance of the people drifts from the Nigerian state to their respective minority groups, a position considered by the government as inimical to the sovereignty of the state and constituted authority.

In response to the agitations of the region, Commissions and Development Committees were set up at different times in the nation's history, these include; The Niger Delta Development Board, (NDDB), Okigbo Revenue Commission, (ORO), Oil Mineral Producing Areas Development Commission, (OMPADEC), Niger Delta Development Commission,(NDDC), Presidential Panel on Amnesty and Disarmament of Militants and, the Ministry of Niger Delta Affairs to mention these few. The rationale for these programmes was to fast-track the development of the region and ameliorates the hardship the people are exposed to. However, the implementation of the programmes leaves much to be desired as corruption, politicization and ethnicity combined to undermine the success of the programmes.

The contestations over resources became pronounced due to the politicization and ethnicization of the proceeds from oil, as well as the "pursuit of developmental paradigm that further polarised the different social and economic groups "in the country by the Nigerian state. (Adedeji 1999:32) To this end, the Niger Delta minority groups believed the arrangement favours the dominant ethnic groups to their detriment. According to Nwankwo O.N, (2015) the principle of derivation which was intended to resolve the developmental quest of the region was a mere palliative. Although, the derivation principle improved over the years from $1.5 \%$ to $3 \%$ and currently is at $13 \%$. But, it was recalled that when agriculture was the mainstay of the Nigerian economy, the derivation principle was $50 \%$ of a state's income but with the advent of oil-boom this was changed. The change was based on the government's argument that oil is an accident of geographical location. This lopsided treatment resorted to loss of faith and hope in the Nigerian federation hence, agitations for regional autonomy, greater allocation of revenue derivable from oil or the re-negotiation of the agreement underlying the existence of Nigeria as a corporate entity. Very recently, one billion United States of America Dollars was approved by the Buhari led administration from the excess crude account to combat insurgency in the North Eastern part of the country, the Niger-Delta militants have demanded the release of equal amount by the government to tackle development challenges in the Niger Delta region or they will begin massive destructions of oil pipelines and facilities. Obviously, the actions of the government which is predicated on patriotism and the threats of the militants anchored on social justice raised some moral questions that border on the ethics of civility.

The questions are multidimensional: is the approval by government in conformity with natural justice by using the resources derived from a neglected region to combat insurgency in another region? Is the Niger Delta region averse to the use of benefits accruable from oil to develop other regions of the federation or it is concern with the neglect of its region in terms of developmental projects? How precisely should benefits and burdens be distributed such that it could be morally defended? Has the oil bearing communities of the Niger Delta region sufficiently shown understanding to the nature and processes involved in oil exploration? Are there no constructive ways for channelling the grievances caused by pollution and other hazards they are exposed to because of the activities of the oil firms? Will control of oil resources automatically transmute the region into eldorado? Will the control of oil resource by the oil bearing communities guide against deep rooted corruption of Nigerians including the host communities? What happened to the chunk of funds released to the region for development overtime?

Has successive governments in Nigeria genuinely introduced/ executed poverty alleviating / developmental programmes directed at addressing the degradation, pollution and underdevelopment occasioned by oil exploration, exploitation and gas flaring by the Multinational Oil Corporations in the Niger Delta region? Or put differently, is Nigeria government sufficiently committed to the welfare of the inhabitants of the region? Has the government adequately implemented the laws protecting the oil communities? Can it be said that the Government has justly distributed the resources generated from the sale of crude oil? Does the environment of the Niger Delta region has rights that the Multinational Oil Corporations must respect and protect?

These catalogue of questions constitute the grouse that each of the parties in the Niger Delta conflict continually raised while defending their group's actions and inactions. The choices and decisions of each of the parties in the Niger Delta 
conflict are dependent on the answers they have to those catalogue of questions. More importantly, the choices and decisions go contrary to each other because the interests pursued are group-centred; they are devoid of general interests. These underscore the necessity of the ethics of civility, which has objectivity, faithfulness and truthfulness as prerequisites to constructive handling of the Niger Delta debacle. This ethics would ensure that the interests of the oil bearing communities, the Multinational Oil Corporations and the state are secured and protected.

\section{The Social Egoistic Conflicts}

In Philosophy, when human action is motivated solely by the agent's interest or when the goal of an action is directed towards the promotion of the agent's desire such action is describe as egoistic. In egoism, therefore, emphasis is on the "self" or the "I". Egoism, strictly construe emphasizes individualism or the ethics of the self; it is a reference to a person's action, particularly when such action is motivated by the ego or self interest. In a broader perspective, action(s) of a group can also be group-centred in the manner in which the action of individual is self-centred, this is the case when a particular group sees its own good as first and superior. When emphasis is on the promotion of what advances a group's interests and, perhaps at the detriment of other group within a larger group, such group manifests social egoism as against social ethics. This suggests that egoism has the individual and group psychology that both relate to social relationships.

In Leviathan, Thomas Hobbes argued that humans are by nature egocentric; they pursued what fosters their survival as individual entity. In the same vein, humans are by nature social beings, it is within the community of persons that the individual's potentials, goals and aspirations could be actualised. The ruling class in a pluralistic state like Nigeria, for instance, is populated by members of different ethnic groups but, as a class her interests are geared towards the protection and promotion of the economic, social, and political structures that would foster their dominance of the national sphere. In the community of persons, there are groups that share things in common and there are groups with different goals. In other words, groups within a larger political group whose views on issues is stronger than that of the larger group or other groups could exist. One or more of ethnicity, political ideology, class, race, profession, or economic interests could be the uniting thread of members of a particular group. In the case of the Niger Delta, members of the indigenous people of the oil communities are not strictly bond together by primordial ethnicity but by the concern they have for economic injustice allegedly meted out to them by the combined forces of the Federal Government of Nigeria and the Multinational oil Corporations. The group alleged gross neglect even at the face of environmental devastation of their communities. The common interest of the group, therefore, is to control the resource in their domain or be allocated revenue that commensurate with the level of destruction and deprivation as compensation. Unfortunately, the violent pursuance of these interests does not give due consideration to the overall interests of Nigerians; the adoption of a technique reminiscent of terrorism in the pursuit of the group's interest is inimical to the region and the country's development. Investors would be scared away, the existing but inadequate social infrastructure in the region would be destroyed and socio-political instability entrenched in the country.

The microscopic lens through which the Federal Government of Nigeria assesses economic justice is such that there should be parity in the entitlements to federating states in the revenues derivable from the nation's resources. The Federal government proclaims, at least in principle, the doctrine of interdependence of states and citizens as the foundation for national development $\mathrm{h}$; it has a duty to ensure that citizens' obligations are beyond their immediate environment to accommodate all Nigerians irrespective of region. In other words, the government believed that any state in the federation should not be excluded in the scheme of development on the ground that nature does not bestow resource on the state or that the available resource (s) of the state has not been exploited. In the light of the above, successive governments in Nigeria see the Nigerian state as a group whose interests and survival must be prioritize above any sectional or parochial interest. In this wise, what constitutes economic justice to the government would pass as economic injustice to the oil producing communities of the Niger Delta region whose conception of justice consists in giving each region its dues from the contributions and sacrifices made to the country. A wide gap exists, therefore, between what constitutes the interest and responsibility of the Federal Government of Nigeria and the oil communities. Until the gap is bridged, peaceful co-existence in the region would remain a mirage.

It will be recall that part of the functions of government is to create enabling environment for the exploration of oil and Gas flaring. It also has a primary duty to protect the lives and properties of the inhabitants of the oil communities, the expatriates and the generality of Nigerians. Furthermore, it has the mandate to make the multi-cultural, multi-ethnic and multi-linguistic constituents a homogeneous country. In achieving these promises some basic things such as minerals are "communally owed". Aptly put, the power of exploration and exploitation of mineral resources including oil is constitutionally and exclusively vested on the government. It also distributes revenue accruable from the resources among the federating states, with the mind-set of ensuring even development among the federating states. However, this has engendered the problem of distributive justice: the oil producing areas alleged the government of marginalization and deliberate exclusion. Three major criteria are opened to the Government in addressing the problems associated with the distribution of social goods, these include; the need, merit and equality criteria. It is not very clear the criterion adopted by 
the Nigeria government but the emphasis of the oil bearing communities has been that benefits in the Nigerian society should be shared according to the amount the regions have contributed to the social goods of the society.

In another development, the principle that underlies the activities of any business organization, especially of capitalist extraction is profit maximization. The Multinational Oil Corporations operating in the Niger Delta is no exception to this principle. The firms often set aside the globally recommended standard of treating the environment as well as its inhabitants in order to maximise profit. Corporate Social Responsibility initiatives that will contribute to sustainable community development, address local grievances and improve livelihood (Idemudia, U. 2009) are carried out just to fulfill all righteousness. The practical commitment to the development of the host communities seems to be considered as limitation on the profit margins of the firms. Although, it is on record that some social services and development programmes were embarked upon by the corporations to ameliorate the suffering of the host communities. Unfortunately, there seems to be a gulf between what the firms have done and what the oil producing communities expected of them: it is either the communities were not carried along in the plans and execution of the programmes or the interventions by the firms are dysfunctional or inadequate hence the continued antagonistic attitude of the host communities. The Multinational Oil Corporations operating in Niger Delta region must strive to ensure that the perceived oppression of the oil communities with the backing of the Federal Government of Nigeria is halted. This is achievable when fair play and justice becomes the guiding principle of operation in the region. The globally recommended standard of treating the environment should not be jettisoned while ideal Corporate Social Responsibility initiatives should be executed. All of these seem to be absent in the relation between the Multinational Oil Corporations, the environment and the inhabitants of the oil producing communities yet smooth oil exploitation and exploration are envisaged .

The actions of the oil bearing communities represented by the oil militants are to prevent smooth operation of the oil firms if employment opportunities cannot be provided, degradation of environment halted and the development of the region prioritize by the government. However, the Niger Delta militants seem to have shifted focus considerably from these goals to agitation for resource control perhaps, because due recognition was not given to their grievances by the appropriate institutions. The militants who were at the fore-front of the agitations harbour some personal motives beneath the region's motives. Politicians who know the strategic importance of the region to the nation's economy and political stability exploit the situation in the region to their advantages. The militant youth are surreptitiously encouraged to disrupt oil production processes abduct oil workers, scare away investors and cripple the nation's economy.

From the above it is cognitively appropriate to say that each of the parties in the Niger Delta conflict pursues the positions that favours own group interests without concomitant consideration for the interests of others. The interests of the oil producing communities does not adequately accommodate the interests of the Federal government, that of the Federal government does not captured completely those of the oil producing communities above all, the interests of the Multinational Oil Corporations is at variance with the environment where they operate and, the interests of the inhabitants of the oil producing communities

In other words, this tendency of members of a group to act or wanting to act so as to promote and protect the interest of their group is what this paper referred to social egoism. What is therefore required to synthesize these diverse interests and enhanced peaceful co-existence among the stakeholders in the Niger Delta crisis is the ethics of civility.

\section{Ethics of Civility}

By the ethics of civility, therefore, reference is to the caring commitments to the well-beings of the self, others and the environment such that it promotes present complacency devoid of compromise for future generations. Put differently, it is the intelligent and objective concern that restrains man from destructive activities on the self, others as well as its environment in the bid to enhance immediate survival. In this sense, the ethics of civility is all encompassing; it countenanced the moral principles of enlightened self interest that involves the trust and understanding that what is done to enhance the quality of life of others, including the ecosystem also enhances one's wellbeing. It also includes the moral duties of gratitude and malfeasance that we owe others as individual or corporate entities in society. Like ethics of nature-relatedness or .ethics of care, ethics of civility is averse to the unrestricted freedom to destroy nature simply to satisfy needs and interests but beyond ethics of nature-relatedness, ethics of civility is concern with our interpersonal relations namely; the relationship between inhabitants of the oil producing communities and others within the territorial space called Nigeria, as well as the relationship between them and the staffers of the Multinational Oil Corporations operating in the Niger Delta region. It also includes the relation between the firms and the ecosystem. It, therefore, differs from the ethics of nature-relatedness or care that emphasizes the human relation with the environment alone

The foundation of any peaceful society must recognized the vital roles of the virtues of tolerance, trust, truthfulness, empathy, respect for the rights and dignity others. These virtues are conspicuously absent in the inter group relations between the Multinational Oil Corporations, the oil bearing communities in Niger Delta as well as the Federal government of Nigeria. Peaceful co-existence would have been better enhanced if they interact with one another on the 
basis of these virtues that constitute the ethics of civility in contemporary society.

The ethics is diametrically opposed to that of incivility. In incivility, interpersonal relations including the relation with nature are predicated on immediate benefits, self or group-centeredness. We act as if today is all we have, no consideration for tomorrow in the dealings with others as well as the environment. It relegated to the background the virtue of care, considerate appropriation and sustainability that underlies the ethics of civility but rather pride self or group-centredness.

The oil bearing communities have been marginalised in the scheme of things in Nigeria. The goose that lays the golden eggs needs to be properly nourished. The Federal government of Nigeria needs to draw out and faithfully implement feasible plans of actions that would address the developmental needs of the region. The author concedes that the country does not lack good development plans, what it lacks is faithful execution of those plans. In surmounting this challenge, the ethics of civility; doing the needful with commitments is instructive. Sincerity of purpose rather than politics should guide the actions of government.

In the same vein, the activities of the Multinational Oil Corporations in the region should reflect best global practices, bearing in mind that "organizations whose cultures respect ethics and civility are more successful" (Aloke Chakravarty 2017: 39) . Part of what escalates the crisis in the Niger Delta region is the absence of "Good oil field practices" (Oyebode Akin 2000: 59) in the operation of the Multinational Oil Corporations. In addition, Ideal Corporate Social Responsibility designed by the oil firms in conjunction with the host communities would address the grievances of the people.

Finally, civility is at variance with violence. The militants and the oil bearing communities of the Niger Delta region should engage in dialogue as a civilised approach in resolving conflict rather than take to violence. The wisdom in the choice of dialogue is overwhelming. According to Julius Nyerere cited in Diana E Axelsen, "Violence is a short cut only to the destruction of institutions and power groups of the old society; they are not a short cut to the building of the new... For violence cannot be welcomed by those who care about people" (1979:193)

The government should not construe the choice of dialogue as weakness on the part of the aggrieved or an opportunity to foot drag in the implementation of policies that will bring the embattled region out of the woods rather, it should be seen as a right step in a civilised and enlightened society and must be appreciated and reciprocated. History has shown that successive administrations in Nigeria pay lip-service to dialogue, sadly, portraying government as good listeners to violent acts rather than non-violent methods. For instance, The United Nations Environmental Programme (UNEP) in its environmental assessment of Ogoni land in August 2011, recommended to the government, the oil and gas industries and communities a clean up of Ogoniland, so as to restore polluted environment and put an end to all forms of ongoing oil contamination in the region. In the last quarter of 2017, Mosop, Pandef and other concerned individuals are lamenting the slow pace of work in this regard. Thus, confirming the alleged insensitivity of the government to the plight of the region. In the words of (Aloke Chakravarty 2017: 41), the government should play a larger role in advocating and shepherding industry governance to articulate meaningful, self imposed ethical standards and to commit to creating cultures of ethics and civil behaviour at all levels of organizations.

\section{Conclusion}

The paper re- examined the incessant violent conflict in the Niger Delta region of Nigeria. It noted that the causes of the crisis included the pursuit of interests that advanced the well-being of members of the different groups that constitute the major stakeholders namely: the Multinational Oil Corporations operating in the region, the oil bearing communities represented by the militant youths and, the Federal Government of Nigeria. In the pursuits of the group-centred interests, less commitment is given to what promotes the general well-being of the society as well as the environment that is being devastated by oil exploration and exploitation. The paper argued for positive attitudinal change directed towards the environment, future generations and the host communities by the Multinational Oil Corporations. It also enjoined the choice of dialogue by the militants as a civilised approach to resolving conflict rather than the resort to violence. Finally, the Federal Government of Nigeria should be guided by fairness, justice and other principles of civility in the design and execution of policies that will facilitate development, ameliorate poverty and enhance peaceful co-existence in the region.

\section{References}

Adedeji, A. (1999). Comprehending and Mastering African Conflicts: The Search for Sustainable Peace and Good Governance Ijebu -Ode: Zed Books \&African Centre for Development and Strategic Studies.

Airoboman, F. A. (2015). Tribalism and the Crises of Nationalism in Nigeria Nationalism and Economic Justice in Nigeria. Yinusa K. Salami, J.O Famakinwa and Gbenga Fasiku eds. Ile-Ife: Obafemi Awolowo University Press. 134-153.

Attfield, R. (1983). Ethics of Environmental Concern. New York: Columbia University Press. 
Axelsen, D. E. (1979). Philosophical Justification for Contemporary African Social and Political Values and Strategies African Philosophy : An Introduction $2^{\text {nd }}$ ed. Richard A. Wright (ed) New York: University Press of America 183-200.

Barbour, I. G. (1993). Ethics in an Age of Technology: The Gifford Lectures 1989-91 vol 2. New York: HarperCollins.

Butler, J. (2009) Frames of War: When is Life Grievable? New York: Verso.

Chakravarty, A.(2017). A call for Ethics and Civility in Governance and Litigation: Changing Culture and Increasing Accountability Emory Corporate Governance and Accountability Review, 4, 37-45.

Falaiye, M., \& Okeregbe, A. (2016). Social Contract Theories and Governance in Contemporary Nigeria Ethics, Governance and Social Order in Africa: Essays in Honour of Godwin S. Sogolo. Olatunji O Oyeshile \& Francis Offor eds. Ibadan: Zenith House. 155-163.

Haaga, T. P. (2015). On Economic Injustice and Distribution of Resources in Nigeria. What Will H.L.A. Hart Say? Nationalism and Economic Justice in Nigeria. Yunusa K. Salami, J. O. Famakinwa \& Gbenga Fasiku (eds) Ile-Ife: OAU Press, 191-208.

Hobbes, T. (1962). Leviathan Or the Matter, Form and Power of a Commonwealth Ecclesiastical and Civil. New York: Collier Books.

Idemudia, U. (2009). Corporate Partnership and Community Development in the Nigeria Oil Industry: Strengths and limitations. Retrieved from www.commder/files/1061-files-7pdf. 28th November, 2017

Ige, O. (2017). Wanted Dead Alive: Palynomorphs as Microscopic Signal to the Past and Present. $11^{\text {th }}$ Inaugural Lecture of Adekunle Ajasin University, Akungba Akoko. Ondo State Nigeria. Delivered at the Olusegun Obasanjo Multipurpose Hall on Tuesday, $28^{\text {th }}$ August 2017.

Institute of Chartered Accountants of Nigeria (2014). Management, Governance and Ethics: Study Text. Berkshire: Emile Woolf International.

Irele, D. (1998). Introduction to Political Philosophy Ibadan: University of Ibadan Press.

Kelbessa, W. (2006). The Rehabilitation of Indigenous Environmental Ethics in Africa. Diogenes, 207, 17-34.

Magesa, L. ( 1997). African Religion: The Moral Traditions of Abundant Life. New York: Orbis.

Meginns, T. (1982). The American Medical Association Family Medical Guide R.M. Kunz. ed. New York: Random House.

Nwankwo, B. O. (2015). The Politics of Conflict over Oil in the Niger Delta Region of Nigeria: A Review of the Corporate Social Responsibility Strategies of the Oil Companies American Journal of Educational Research, 3(4) 383-392.

Ogungbemi, S. (2010). The Conflict in the Niger Delta and National Interest. Oil Violence in Nigeria: Checkmating its Resurgence in the Niger Delta. Victor Ojakorotu \& Lysias Dodd Gilbert ed. Johannesburg: Lambert, 167-180.

Olanrewaju, U. (2014). Corporate Social Responsibility of Corporations to Host Communities. Business Day Newspaper. Retrieved from

www.businessdayonline/com/2014/09/c0rporate-socilresponsibility-csr-of-corporations-to-host-communities/\#.VZ uxOPwo-TK. $28^{\text {th }}$ September, 2017

Oyebode, A. (2000). The Legal Framework of Oil Exploration in Nigeria: A Critique Boiling Point Wunmi Raji, Ayodele Ale \& Eni Akinsola (eds) Lagos: Committee for the Defence of Human Rights.

Taylor, W. P. (1986). Respect for Nature: A Theory of Environmental Ethics. Princeton: Princeton University Press.

Temitope, A. R. (2006). Applying the Right to Development to Ethnic Nationalism in Nigeria's Niger Delta Region. The Humanities, Nationalism and Democracy Sola Akinrinade, Dipo Fashina and David O. Ogungbile ed., 192-209.

UNDP (2000). Niger Delta Human Development Report Abuja: United Nations.

\section{Copyrights}

Copyright for this article is retained by the author(s), with first publication rights granted to the journal.

This is an open-access article distributed under the terms and conditions of the Creative Commons Attribution license (http://creativecommons.org/licenses/by/4.0/). 